\title{
Architects in Motion - Reasons, Conditions, and Consequences of Professional Migration from Russia and the Soviet Union to Italy, France, and Great Britain in 1905 - 1941
}

\author{
Stéphane Gaessler ${ }^{1, a} K_{s e n i a ~ M a l i c h}{ }^{2, b}$ Ilya Pechenkin $^{2, c}$ Anna Vyazemtseva ${ }^{2, *}$ \\ ${ }^{1}$ Institut National d'Histoire de l'Art, France, Paris, France \\ ${ }^{2}$ Scientific Research Institute of Theory and History of Architecture and Urban Planning, branch of the Central \\ Institute for Research and Design of the Ministry of Construction and Housing and Communal Services of the \\ Russian Federation (Russia), Moscow, Russia \\ astephane.gaessler@inha.fr \\ ${ }^{b}$ kseniamalich@gmail.com \\ cpech_archistory@mail.ru \\ *Corresponding author. Email: anna.vyazemtseva@gmail.com
}

\begin{abstract}
During that special period of Russian history between the First Revolution 1905 and the Second World War, the profound changes of construction industry, of traditional systems of architectural education, together with cardinal socio-political transformation of the country profoundly modified architectural profession. A lot of professionals had to leave the country due to social cataclysms. The aim of the paper is to draw up as much as possible a complete picture of the emigration of architects from Russia to Italy, France, and Great Britain, analyzing the circumstances of the emigration and the further careers of those architects and describing the heritage they left, as well as to estimate their place and role in the history of architecture.
\end{abstract}

Keywords: Twentieth century architecture, Russian architecture, Soviet architecture, Architects of the Russian emigration, Neoclassicism, Avant-garde, Modernism, Russian style, International relations, Cultural exchange between Italy, France, Great Britain, Russia, and the U.S.S.R., Transnational art history.

\section{INTRODUCTION}

As early as in 2004, V.L. Khait wrote: "Interest in the works of Russian architects abroad is important from the modern point of view of the necessity to build a more complete and objective history of Russian architecture and, respectively, with expanding the typological and geographical 'boundaries' of Russian architecture, as well as with a reassessment of its input into the world architecture" [1]. However, until now, such a study, which would describe, analyze and generalize the

*The research is funded by the grant for cooperation of Russian Foundation for Basic Research and National Center for Scientific Research of France (International Emerging Actions), project n. 21-512-15002, dir. by Anna Vyazemtseva (Russia) and Jean Battiste Minnaert (France). legacy of Russian architects, created outside of Russia in the age of revolutions and cardinal social and scientific transformations, has not been done. The topic is gaining even greater relevance today, both in the context of numerous publications about certain persons and individual stories of Russian architects who worked in emigration, as well as in the context of emergence of historical distance necessary for the analysis. Besides, nowadays, there are new approaches in historical research, art history and architectural studies, revealing new interethnic and intercultural contacts and their place in the social history of countries ${ }^{1}$, especially in the

1. See "Transnational History of Art History", ongoing research project of Hertziana Library - Max Institute for History of Art in Rome, led by Tristan Weddigen or "AdriArchCult — Architectural Culture of the Early Modern 
twentieth century, giving new ideas about international relations both at the turn of the century and in the years of political confrontation between the capitalist and socialist world, opening up new ways of understanding national interaction.

\section{THE 'GRAND TOUR' IN THE RUSSIAN STYLE AND EMIGRATION: ARCHITECTS ABROAD BEFORE THE OCTOBER REVOLUTION 1917}

The tradition of granted trips provided for the best graduates of the St. Petersburg Academy of Fine Arts has always been of great importance, but for Neoclassicists architects who entered the professional field in 1900-s Italy was a sacred place.

At that time, the interest in the legacy of Andrea Palladio grew in Europe; monographs by Sir Banister Flentcher [2], and Fritz Burger [3] about him were published. But it was Russia, where a certain cult around the name of Palladio was shaped; and its main 'priest' was Ivan Zholtovsky. In particular, the manor house in Lipovka was built by him in 1906-1907 for the Italophile Alfred Ruperti after the Villa Badoer in Fratta Polesine. In the early 1910-s, Zholtovsky generously quoted constructions of Palladio in the composition of the façade of the Gavriil Tarasov mansion in Moscow (imitating the façade of the Vicentian Palazzo Thiene), and in the non-implemented draft of the project of the Russian Pavilion at the International Exhibition in Rome (varying the famous composition of the Villa Rorunda) [4].

In 1905, a young graduate of the Academy, Vladimir Shchuko, went to his granted trip, the route of which had been designed by Zholtovsky and Alexey Shchusev. The tour was started from Constantinople (Istanbul) and ended in the north of Italy [5]. The trip, interrupted by the revolutionary events in Russia, was resumed in 1906: through Vienna and Trieste, Shchuko returned to Venice, visited Bologna, Ferrara, Cremona, Verona, Padua, Vicenza, and Mantua, and then came to Rome again.

His impressions got in Italy were reflected in the pre-revolutionary creative works by Shchuko not less vividly and openly that such ones in the

Eastern Adriatic", research project financed by European Research Council in 2020 and lead by Jasenka Gudelj, University of Venice Ca' Foscari. projects of Zholtovsky. His ideas in the gender of the countryside villa - the projects of the Count Mordvinov's dacha on the Kamenny Island (St, Petersburg, 1915), and the Rener's mansion by Odessa (1916) - were not fulfilled. But the main contribution by Shchuko to the formation of Neoclassicism was connected with large multistoried buildings. As a practitioner, he started with two apartment buildings in the Kamennoostrovsky Avenue in St. Petersburg (1909-1910), where his task was to find an image of façades, because the inner planning structure had been worked out by the owner-developer, military engineer Constantine Markov. The young architect, who had just returned from his granted trip, offered two variations on the theme of the Italian Renaissance; at that, the second of the buildings with monumental semi-columns and a loose cornice (\#65) - gave rise to a whole line in the prerevolutionary Neoclassicism.

Thus, it is difficult to overestimate the importance of Italian trips for the destiny of Russian architecture of the early twentieth century. "The pilgrimage to the city of Palladio, started by Zholtovsky, was not in vain for the history of the evolution of the new architecture of St. Petersburg" [6], noted critic Georgy Lukomsky in 1913. Sending academics to Europe was broken with the WWI due to political and economical difficulties.

The emigration of architects from the Russian Empire just before 1917 was quite insignificant, which strikingly distinguished architects from masters of the fine arts. One of the reasons for such low mobility of Russian architects was their aesthetical conservatism. Circa 1910, when easel painters were involved into radical formal experiments, architects deepened their mastership in the language of architectural order, increased monumentality of images, appealing mainly to samples of the Italian Renaissance and Russian Classicism [7]. In 1910-s, in Russia, the only serious alternative to Neoclassicism was the so called Neo-Russian style, and with such approach there was no career prospects for Russian architects abroad.

That choice became inevitable for some of Russian architects after the revolution 1917. Among the architects-emigrants of the first wave there were masters who were at the peak of their professional success at the moment. So, soon after graduating from the Leontiy Benois class of the Higher Art School of the Imperial Academy of Fine Arts, Andrey Beloborodov was the author of a 
design project for the Main Hall at the Cabinet of His Majesty in the Anichkov Palace (the project was accepted but not implemented because of the outbreak of the WWI). In 1914-1916, Beloborodov was engaged into the restructuring of the interiors of the Yusupov Palace in Moika for the young Prince Felix Yusupov and his wife, Imperial Princess Irina Alexandrovna Romanova. In his memoirs, the discerning Prince Sergey Shcherbatov called Beloborodov a rival to Zholtovsky "in his knowledge of Italy" [8]. As for the proximity to the court order, Beloborodov has far surpassed his colleagues; one may only judge what prospects would be open before him in the future. But the fate of the country turned another way, and, in 1920, Beloborodov emigrated.

"Hardly a person had got the first steps of the ladder that would have lifted him to the position of a Russian Mansard, and then everything around flew to hell" [9], - wrote Alexander Benois in his diary, referring another pre-revolutionary Neoclassicist, Alexander Tamanov (Tamanyan). An attempt of Tamanov to consolidate his high position through cooperation with the Provisional Government as the Commissioner of the Academy of Fine Arts failed due to the change of power in October 1917; so, his salutary departure to Armenia was a kind of emigration.

Alexander Wladovsky, Stanislav-Witold Nowakovsky, Marian Lialewicz rushed to the outskirts of the former empire, which gained independence. Wladovsky went down in history as the founder of the Estonian school of architecture; Nowakovskey and Lialewicz worked fruitfully in Poland. In the revolutionary years, a representative colony of architects gathered in the Crimea, where numerous intelligentsia tried to find an escape from the upheavals in the capital [10]. For some of them - for instance, for Leonid Brailovsky or Nicholas Vassiliev - the Crimea was the initial stage of emigration.

\section{ARCHITECTS-EMIGRANTS AFTER THE REVOLUTION - THE GEOGRAPHY OF THEIR MOTIONS AND ACTIVITY: BERTOLD LUBETKIN}

In the long list of Russian architects, who worked in Western Europe after the Revolution 1917, the name of Berthold Romanovich Lubetkin, who became one of the leaders of the British modern movement, stands out. The success of his architectural career is rather an exception for the Russian emigration: therefore, it is especially interesting to consider his professional contacts and the path that he passed from the moment of leaving Russia in 1922 up to moving to England.

Lubetkin was only twenty years old when he left Russia, but the liberal views of his family, the revolutionary events, and finally, his studies at the Petrograd and Moscow Free State Art Workshops, transformed into the VKHUTEMAS in 1920, had a decisive influence on his artistic preferences. First of all, it was his belief in the experiment of the Avant-garde and new architecture. After Moscow, he studied at the Warsaw Polytechnic (1923-1924), then he moved to Paris, where he attended both the Ecole Speciale (1925) and the Ecole des Beaux Arts (1926), and, then, he signed as a listener to the Ecole Suerieur de Beton Ame and to the Institut d'Urbanisme of the Sorbonne (1930-1931). He also had a chance to see how the workshop of Auguste Perret worked, and, at that time, Perret was in charge of a group of students of the School of Fine Arts.

Even in the cursory sketches of his later unpublished memoirs 'Samizdat by Anarchitect' [11] one can see an incredibly diversity of his cultural environment, where his contacts with Russian artists and writers were very intense. In the café 'Lilas' and in other fashionable establishments Lubetkin met Ehrenburg, Malevich, Rodchenko, Sutin, Goncharova, and Larionov. Together with Annenkov, he organized the 'Vingt-Cinq' group in support of contemporary art. In his 'Samizdat', Lubetkin recalls how he met his St. Petersburg professor, architect Dubinsky, over a plate of Russian borscht in one of such café. Together with another acquaintance from Russia, Bobka Rodionov, they painted the 'Club Trapeze Volant', arranged in an old garage on the order of the circus acrobat Roland Tutin; and later he worked on the design of one of the pavilions of the International Colonial Exhibition (1931).

The deplorable financial situation forced Lubetkin to take on any job, for any opportunity, any contact. An aspiring architect-expat without a diploma, experience and connections had practically no chance of a professional order. But Lubetkin was saved by the Trade Mission of the U.S.S.R. in France, for which he worked as a translator from time to time, receiving a "meager payment... which was hardly enough for travel" [12]. Soon enough, the designer Franz Jourdain (a convinced Communist who sympathized with the 
Soviet Republic) persuaded the Trade Mission to entrust Lubetkin with a more responsible job. At that time, the Soviet government kept an active foreign trade policy and was interested in the popularization of Soviet goods. The Paris office received a ready-made project for the exhibition pavilion "in the Melnikov style", but it had to be correctly interpreted and built ("Figure 1"). Lubetkin was to figure out the idea of the engineer Volodko, then to find suitable local materials, to implement the project and to accompany the structure at all trade shows. In an explanatory note from August 9, 1929, the architect wrote that since the expenses of a one-time erection of the pavilion are inexpedient, he invented a demountable structure and slightly changed the initial proportions. As a result, the shape and the size of the structure could be changed depending on the quantity of exhibits, and the structure could withstand four installations. From 1928 to 1931, the Soviet pavilion visited exhibitions in Strasbourg, Marseille, Bordeaux, and Nancy. Lubetkin also acted as a courier interpreter.

In 1931, Lubetkin took part in the competition for the construction of the Palace of Soviets. He had previously participated in Soviet competitions, the programs of which reached Paris: in 1925, it was the project of the Polytechnic University in Sverdlovsk; in 1931, the project of the building of the Tsentrosoiuz (Central Union). He prepared a project of the Palace of Soviets together with his friend Grigory Sigalin. Lubetkin recalled Sigalin's confidence that "only in Russia one can implement those large-scale projects that he dreamed of" [13].

In 1931-1932, Lubetkin seriously discussed the idea of moving to the U.S.S.R. with one of Soviet officials (the signature of his correspondent is illegible, but most likely it is G. Kivkutsan, the former chairman of the exhibition bureau of the Trade Mission in Paris.); he official described to the architect "decaying capitalism", which "cannot build anything grandiose", only "villas for some kept woman..." [14] At the same time, Lubetkin talked about the moving with a relative, who offered to seek assistance from B. Iofan [15]. Although Lubetkin specifically noted in his letters that the reasons for his move were exclusively ideological, not financial, it was precisely the lack of earnings that prompted Russian architects (and not only them) to think about returning to Russia. But the shocking outcome of the Palace of Soviets competition, which disappointed the supporters of the Modernist movement, made the idea of returning to the U.S.S.R rather controversial. New contacts in London, which Lubetkin got in 1931, through his Russian acquaintance Praskovya Shuberskaya ${ }^{2}$, predetermined his destiny. Praskovya introduced Berthold to Margaret Gardiner, who recommended the architect to Godfrey Samuel, with whom he later founded the Tecton architectural firm.

Aneway, in 1934, Berthold Lubetkin visited the U.S.S.R. ${ }^{3}$ to collect the fee for participating in the competition for the Palace of Soviets. He did not get a job there, but on the way back he met his future wife Margaret Church. [16] In 1934, Lubetkin's affairs improved. If, in 1932, he and Grigory Sigalin had to sell Polish kefir in order to survive in London, in 1934, Tecton already received and implemented several interesting orders: the pavilions of the London Zoo and townhouses in Plumstead. The latter project became possible thanks to an acquaintance with an architect of Polish origin, Ammon Piliczowski (in his memoirs, Lubetkin, though, mentions his Russian roots $[17]^{4}$. Lubetkin joined the MARS group and finally established himself as one of progressive British architects. Perhaps, the move to England saved Lubetkin not only her creative career, but also the life. In 1942, his father died in Auschwitz - it was a terrible fate awaited many of his friends who remained in Paris.

2. In Paris, Lubetkin left at her father's a case with drawings by Malevich, Tatlin, Popova, Rodchenko, and Dexter. Returning to Paris after the WWII, he could not find any traces of that small collection.

3. The group included Francis Skinner, Robert Townsend and Geoffrey Vevers from London ZOO.

4. Amnon Vivien Pilichovsky (1907-1982), in England took the pseudonym Vivien Pilley. 


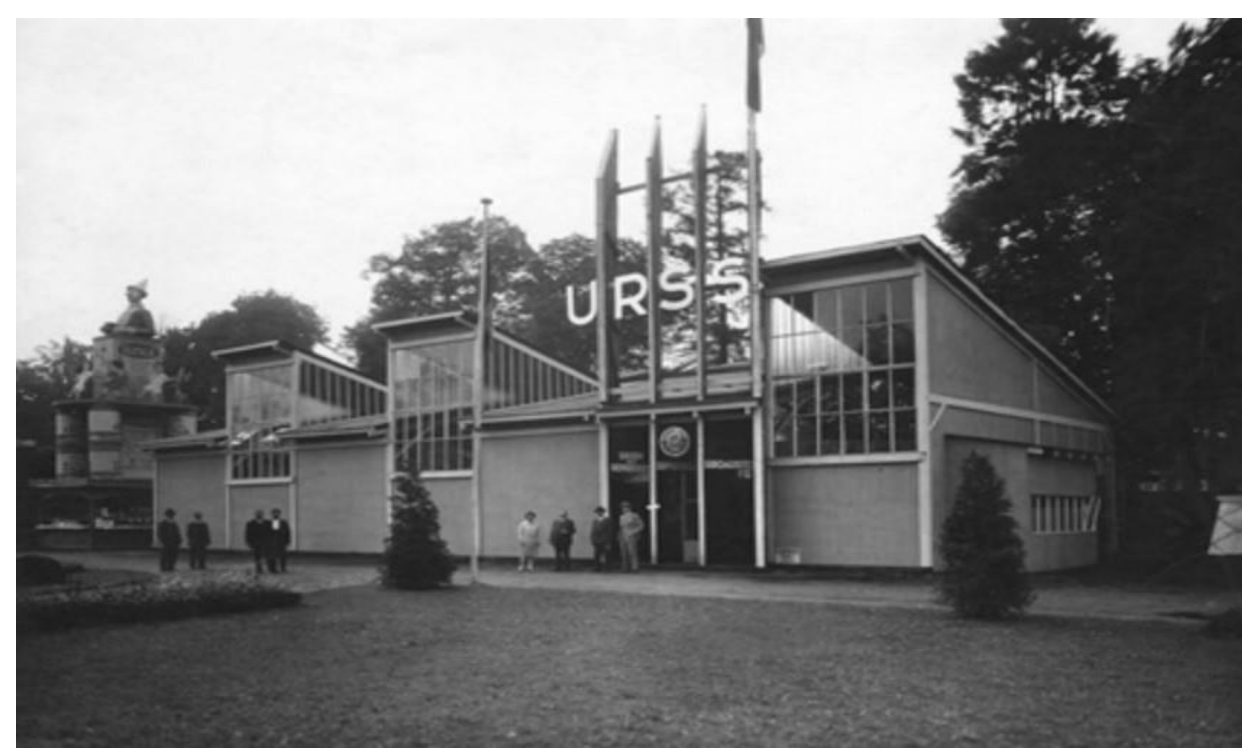

Figure 1 Berthold Lubetkin. Soviet pavilion in Marseille (designed in 1928). General view. 1928 - 1931. The UK. London. RIBA Archive.

\section{THE PECULIARITY OF ACTIVITY OF RUSSIAN AND SOVIET ARCHITECTS IN ITALY IN 1920-S $-1930-S$}

To understand the peculiarities of the professional activity of foreign architects in Italy, first of all, one should turn to the example of one Russian architect who worked quite successfully in the Italian capital in the early 1920-s; it was Boris Iofan. He graduated from the Architectural Institute of the Academy of Fine Arts (1914-1916) with brilliant grades ${ }^{5}$, Iofan started working for the famous architectural firms Armando Brasini and Giulio Barucci, married the aristocrat Olga Ruffo and became close to the Russian diaspora [19] and socialist circles, and also implemented a number of projects for building cooperatives of budget housing, participated in the restoration of cities in Calabria after the earthquake of 1915. The list of his buildings is given in the biography of I.Yu. Eigel [20]; however, it is noteworthy, that the participation of the architect in their construction is rarely documented. The reason was that Iofan did not have an independent practice; besides, in Italy, before the opening of the Higher School of Architecture at the University of Rome in 1920, graduates of architectural classes of the Academy of Fine Arts got a diploma of 'professor of architectural drawing' and did not have the right to sign construction projects [21]. The rise to power of

5. Iofan successfully obtained the graduateion in June of 1916 with the grade 50/50 cum laude (Archive of Academy of Fine Arts of Rome, personal folder of Boris Iofan).
Benito Mussolini on October 28, 1922, and the gradual establishment of the dictatorship of Fascism, undoubtedly made private and professional life difficult for the architect, who took part in the creation of the Italian Communist Party a year earlier. In 1924, he left for Moscow at the invitation of Alexei Rykov [22], who made a visit after the recent establishment of diplomatic relations between the countries. This move, of course, became decisive for the professional life of Iofan, turning him from one of the many employees of Roman architectural firms into a key person in the history of Soviet (and not only Soviet) architecture.

It is known that Iofan communicated in Rome with representatives of the Russian emigration, but we do not know if he met Andrei Beloborodov, who settled in Paris, but visited Italy already in the early 1920-s. "And finally, I am in Rome, — the architect wrote in his memoirs [...]. From that moment I began that vast work of my life, which continues up to this day and, I hope, will continue until the end of my days: the cycle of my images of Italy, its paesaggio architettonico" [23].

Since 1925, Leonid Brailovsky and his wife Rimma lived in Rome, together they made a large series of paintings for the Vatican, depicting 'leaving' Russia in order to preserve the memory of Russian ecclesiastic architectural heritage disappearing in the process of the anti-religious struggle in the U.S.S.R. The collection (over 100 works) is kept in the Congregation of the Oriental Churches of Rome. However, Brailovsky's 
architectural practice was very scarce. In 1937, he designed a church in Ostia in the so-called 'Novgorod style' [24], but as a "designer of the façade" and not as an architect [25].

Russian emigrants were also among the students of the Higher School of Architecture opened in Rome in 1920. Noteworthy, the Russian émigré Alexandra Biryukova was among the first two female graduates of the faculty (1925). She not only successfully completed her studies, but also passed the state exam, which gave her the right for professional practice. However, just joining the union of architects in 1929 [26], she left for Canada, to Toronto, where her sister had already settled. Another student was Evgenia Averbukh, who studied in Rome from 1926; she also left Rome in 1929, and then became a famous architect in Israel. In 1932, Vladimir Volkonsky (Wolkonsky), from a well-known Russian aristocratic family, graduated from the architectural faculty in Rome. Soon he designed the first Russian Orthodox Church in the city of the Holy See - the Church of St. Nicholas, built in the house of the Chernyshev Princes on Via Palestro [27]. However, that project was signed not by the Russian author, but by the Italian engineer Ferdinando Poggi. In the same 1932, Volkonsky successfully passed the state exam in Milan, but there is no information about his further practice.

The only Russian architect who succeeded to implement several significant projects in the Eternal City was Andrey Beloborodov [28]. Although his graphic works were quite popular among collectors and were published in famous magazines, in 1930-s, Beloborodov did not build in Italy; he worked at the castle of the Counts de Moutiers-Colencours in France. He started his first Roman project - the reconstruction of the ceremonial courtyard of the villa of Maurice Sandoz on the Aventine Hill - in 1938. The architect did not have the Italian citizenship and he was not a member of the trade union, so, he started his regular professional work in 1950-s only, after the fall of the Mussolini regime. He was loyal to the restrained Neoclassicist style, which he had got in Petersburg, and it aroused some interest among the Roman public. He executed the project of the villa of the publisher Giacomagnello in the Roman district of Monte Mario; he also designed a garden ensemble there [29] ("Figure 2"). Soon after it, he got orders from two other convinced Classicists: the artist Giorgio de Chirico and the art historian Mario Praz, but the architect had possessed already no time to fulfill them.

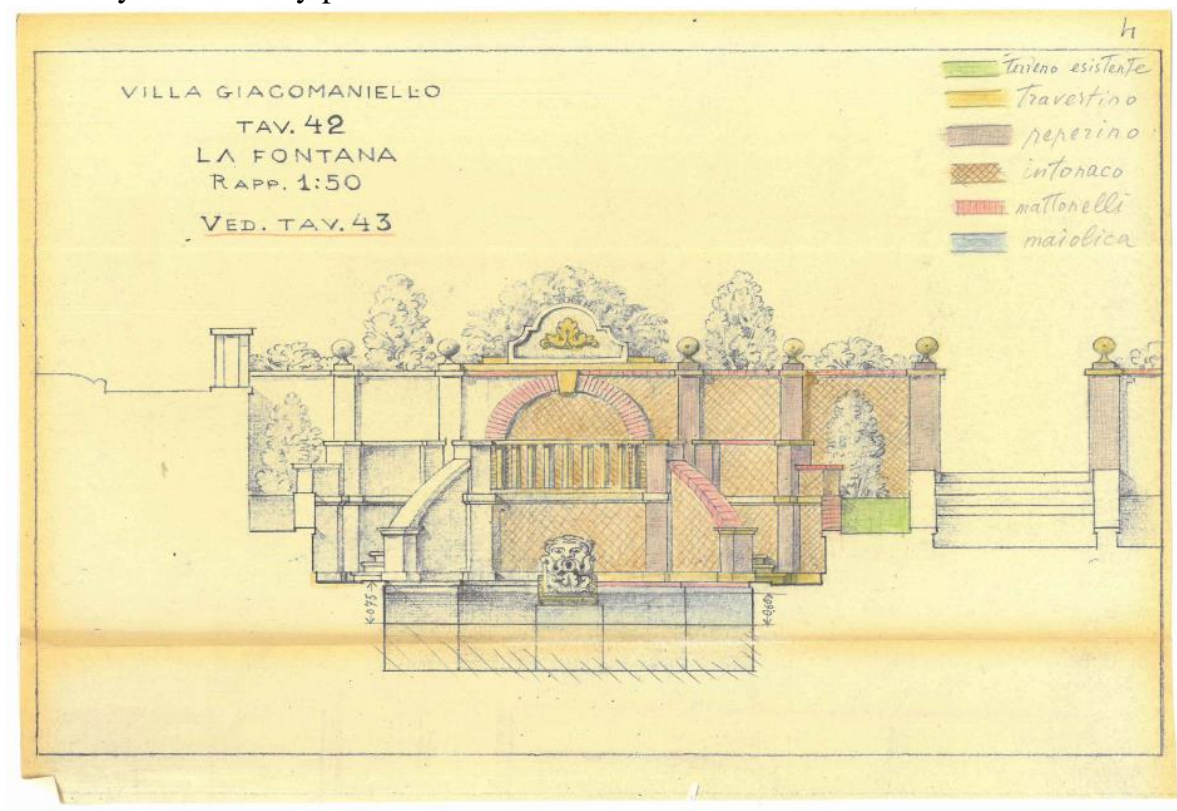

Figure 2 Andrea Beloborodoff (Andrey Beloborodov). Villa Giacomaniello. Rome, 1950s. Vyacheslav Ivanov Archive, Rome.

Those cases show that the professional careers of Russian architects emigrated to Italy in the early 1920-s were rarely successful; it happened, first of all, due to bureaucratic regulations, a highly competitive local professional community, as well as the rarity of orders from other Russian expats. Some work in the field of visual arts was a way to pursue a creative career and to keep in touch with the local cultural environment. The architectural heritage of Russian emigrants in Italy and, in 
particular, in Rome, is incomparably fewer than their graphic heritage.

\section{FRENCH-SOVIET ARCHITECTURAL HISTORY}

Among the most prominent representatives of the early Russian expat architects in France, Ivan Ivanovich Fidler (1890-1977) is of particular interest. Ivan Fidler went to study in France before the WWI, receiving his diploma in architecture at the Special School of Architecture in Paris in 1914. He returned to Russia and in order to get an opportunity to work in his country, he continued his studies as an architect at the Moscow School of Painting, Sculpture and Architecture, where he got the rank of architect-artist. The architecture historian Igor Kazus provided us with particularly valuable information about Fidler's career in Russia, which was far from trivial. He found in archives [30], that on May 10, 1918, Fidler applied to the construction department of the Moscow City Council for admission to the vacant position of the Workshop of the Municipal Construction Department, indicating that he got a Special Education at the Higher School of Architecture in Paris. Then, Fidler became a member of the Art and Construction Subdivision of the Moscow Artistic Collegium of the People's Commissariat of Education, where, according to the traditional division of the three types of art, Malevich was in charge of painting, Boris Korolev on sculpture, and Fidler on architecture. After it, Ivan Fidler worked as deputy of Ivan Zholtovsky, at the time - Head of the Art and Architecture Department of the People's Commissariat for Education, and a member of the department's management board. Within this organization, he was in charge of the School Subdivision. It is noted, that Fidler was awarded with one of the top premium for his project of the crematorium in Moscow - with I.A. Golosov and N.I. Istselenov — in February 1919 [31]. In the monographic study on Konstantin Melnikov [32], Selim Khan-Magomedov mentions Fidler as one of masters at the Architectural Workshop of the Mossovet (city council) — they worked over the project of re-planning of Moscow 'New Moscow' under the supervision of Ivan Zholtovsky and Alexey Schusev. Melnikov recalls: 'we were 12 apostles' — beside Melnikov and Fidler, there was N. Ladovsky, the Golosov brothers, L. Vesnin, A. Rukhlyadev, I. Greenberg, V. Kokorin, E. Norwert, S. Chernyshev, and A. Polyakov. The latter then emigrated to France, where he created an architectural enterprise in Paris together with Fidler. Khan-Magomedov also says that, together with Melnikov, Fidler and Polyakov, they worked on the layout of the Khodynskoye Field (1920). The scholars Yu. Bocharov and S. Tkachenko noted, that the plan of redevelopment of the Khodynskoye Field provided for the construction of a new administrative and political center of the U.S.S.R. [33] How did it happen that an architect who had started such a promising career in the U.S.S.R decided or was forced to emigrate and pursue a career in France?

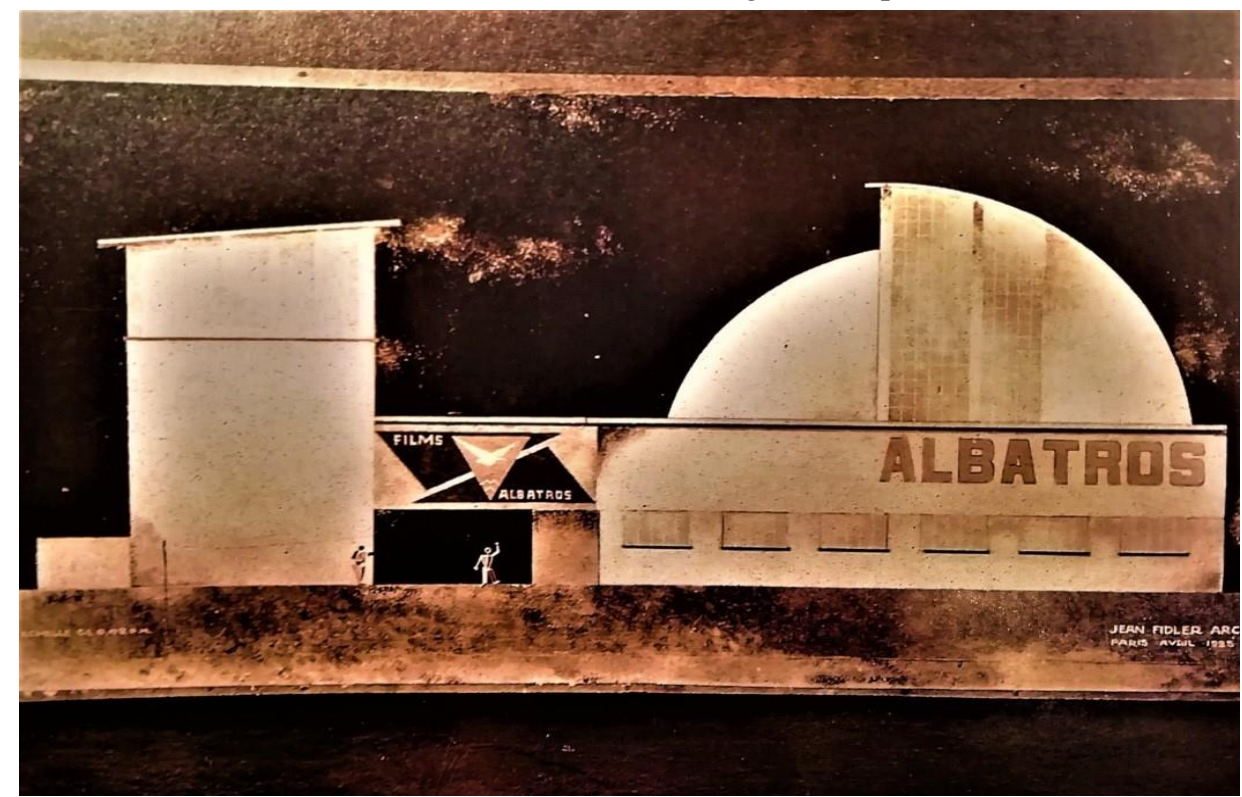

Figure 3 Ivan Fidler, A project for the Albatros Cinema Studio, April 1925, Archival Collections of the French Cinemateque, Paris. 
After 1919, in France, Fidler got his first job at the agency Lucet and took part in the post-war reconstruction of the town of Varennes-enArgonne. In 1925, Ivan Fidler designed an unrealized complex of the Albatross film studio, a French film company founded in 1922 by the Odessa film producer Alexander Kamenka (18881969) [34] ("Figure 3"). Fidler proposes a Constructivist architecture that refers to an astronomical observatory. The cubo-futuristic composition of geometric volumes, asymmetrically located, with the motif of a glass wall, combined elements inherent in the young Soviet Avant-garde [35]. In 1925, he received the first important order on the mansion of the director of the Boston
Symphony Orchestra, Sergei Koussevitsky, in the 16th arrondissement of Paris [36]. Fidler founded the agency in Asnières-sur-Seine, where he worked with his brother Alexander until he died in 1928. Then Ivan Fidler opened his workshop at 26 Champs Elysees, and for six years he has collaborated with Alexander Polyakov, with whom he had already worked on 'New Moscow'. Fidler worked mainly for elite clientele: artists, music hall performers and movie stars, built private mansions and villas for them both in the western suburbs of Paris and on the French Riviera. For instance, it was the villa built in 1930-1932 for the couturier Jean-Charles Wort (1881-1962) in Neuilly-surSeine ("Figure 4").

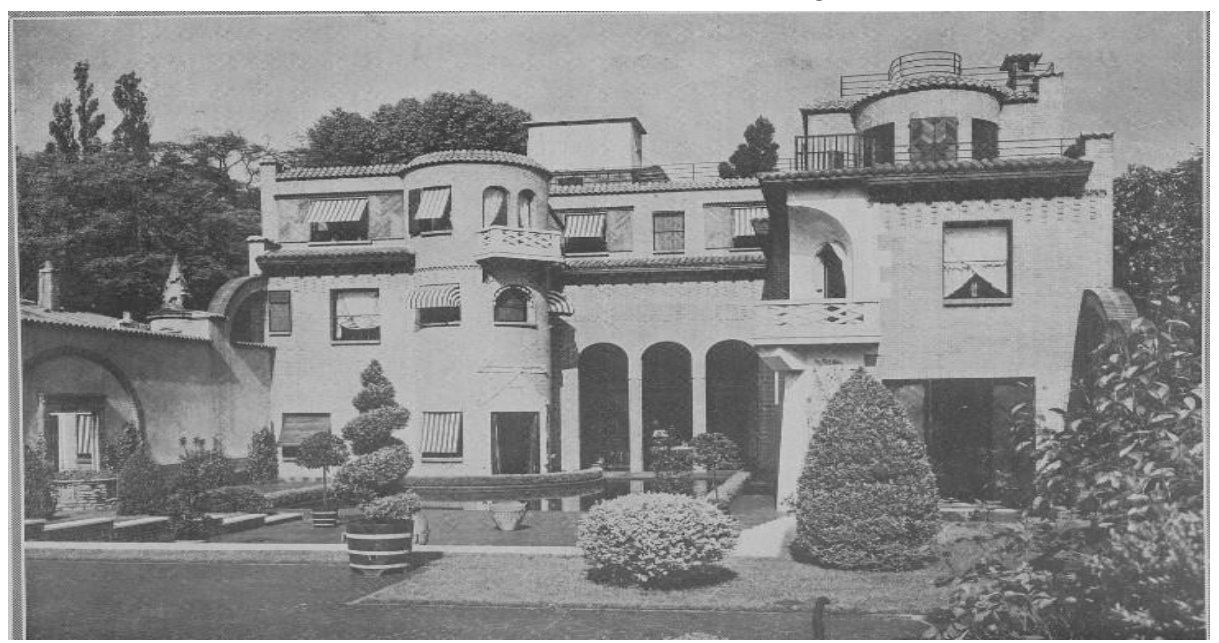

Figure 4 I. Fidler, A. Polyakov, Hôtel Worth, 1930-1932, 83, rue de Longchamps, Neuilly-sur-Seine. From: La construction moderne, revue hebdomadaire d'architecture, n. 21, 19 février 1933.

Fidler specialized in the construction of luxury apartment buildings in Paris, including, in 19351937, together with the architect Boris Loshak, a luxury apartment building 1 Avenue Paul Doumer, for Berthe Astier [36] ("Figure 5"). The building has been keeping its character as a luxury housing till nowadays ("Figure 5").

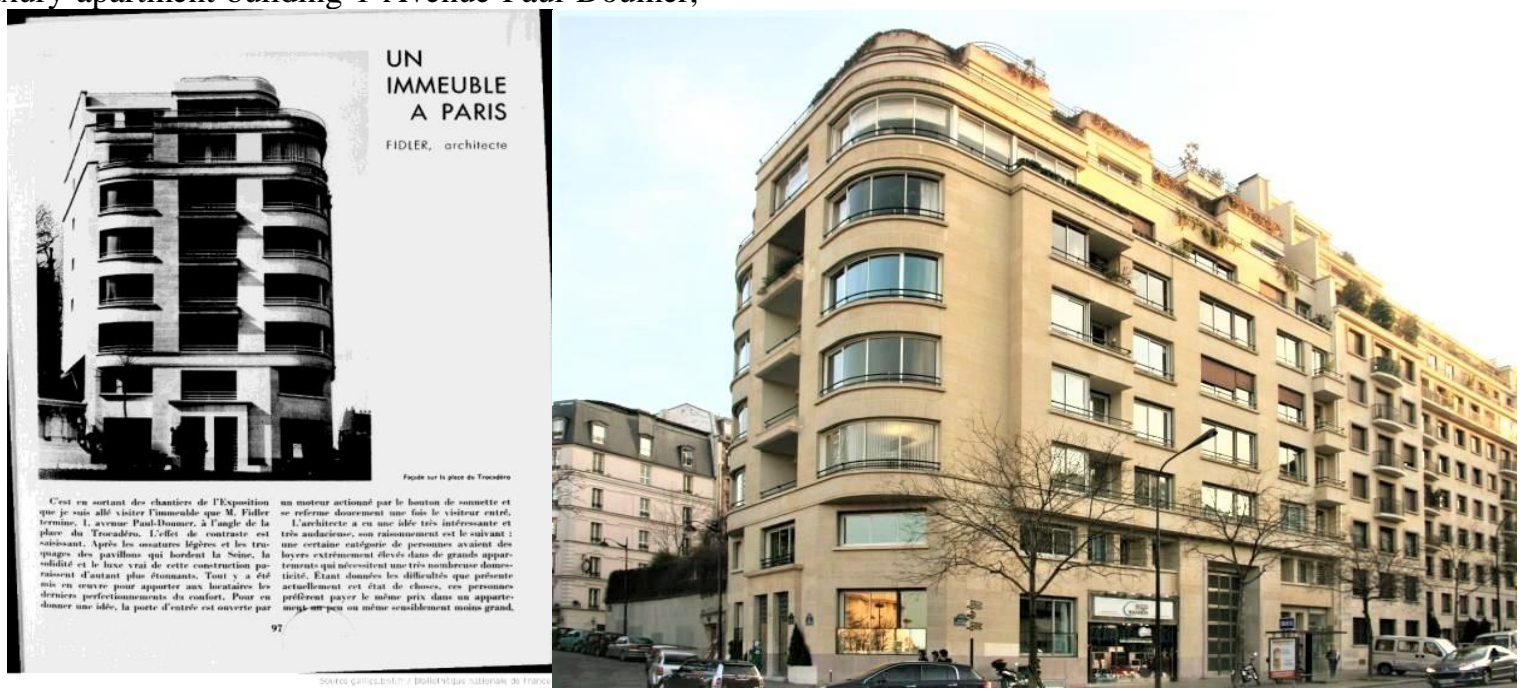

Figure 5 I. Fidler and B. Loshak, Apartment building in Paul Doumer Avenue, 1, 1935-1937. Photo of 1937 


\section{CONCLUSION}

The paper for the first time puts together the works by Russian born and professionally formed architects and different contexts of their foreign careers before and after the Revolution of 1917. Described examples show the diversity of the creative careers of emigré architects and their dependence on the circumstances of a particular country. So, if in Italy their architectural heritage is performed in single samples, often the architects could not even build (Brailovsky), then in France it is richer, more diverse and significant in the general context of French architecture of that period (Fidler). In Great Britain, works by the Russian emigrant B. Lubetkin became one of the defining factors of the formation of the architecture of Modernism. All described cases are considered by the authors as a basis for the further analysis.

\section{AUTHORS' CONTRIBUTIONS}

Ch. II (I. Pechenkin) deals with the prerevolutionary forms of Russian architects' abroad activities such as granted trips for the graduates of Academy and emigration. The author reveals the reasons for the tiny percent of architects among the emigrants from Russian Empire, and explains why the most of Russian architects in Europe before 1917, were the travellers which have been seeking for impressions or education. In the ch. III, based on mainly unpublished archive materials from London RIBA collection, the author (K. Malich), makes an attempt to understand, through the research on the early days of Berthold Lubetkin career in France and UK, the relationships of former Russian emigrants in the professional area, opportunities of getting an order in Europe and motivation to work. Ch. IV (A.Vyazemtseva) describes, introducing unpuplished biographical data from Russian and Italian archives and analyzing local condition of architectural practice, career success and troubles of Russian émigré in Italy. The ch. V (S. Gaessler) for the first time dedicates a single study to creative work by I.Fidler gethering his Russian and French career. "Figure 1" and "Figure 2" are unpublished.

\section{REFERENCES}

[1] V. Khait, Problems and methods of research of architectural creation by Russian architects abroad and Russian emigrants (Problemy i metody izucheniia arkhitekturnogo tvorchestva russkikh arkhitektorov za predelami Rossii i russkikh emigrantov), in: Questions of World History of Architecture (Voprosy vseobshchey istorii arkhitektury) 2 (2004) 236-239 [in Russian].

[2] B. Fletcher, Palladio, His Life and Works, Bell, London, 1902.

[3] F. Burger, "The villas of Andrea Palladio. A contribution to the history of the development of Renaissance architecture", ("Die Villen des Andrea Palladio. Ein Beitrag zur Entwicklungsgeschichte der RenaissanceArchitektur"), Klinkhardt \& Biermann, Leipzig, 1909 [in German].

[4] I. Pechenkin, O. Shurygina, Some New Episodes from I.V. Zholtovsky's Creative Biography (Novye epizody tvorcheskoy biografii I.V. Zholtovskogo), Academia. Architecture and Construction (Academiia. Arkhitektura i stroitel'stvo) 4 (2020) 23-31. DOI: https://doi.org/10.22337/2077-90382020-3-48-54 [in Russian].

[5] L.A. Il'in, V.A. Shchuko [unpublished paper], Russian State Archive of the Economy, f. 377, inv. 1, item 314, pp. 16, 17 [in Russian].

[6] G.K. Loukomski, Modern St. Petersburg (The Thinking on Contemporary Building) (Novyi Peterburg (mysli o sovremennom stroitel'stve), Apollon 2 (1913) p. 18 [in Russian].

[7] G.I. Revzin, Neoclassicism in Russian Architecture of the Beginning of the $20^{\text {th }}$ Century (Neoklassitsizm v russkoi arkhitekture nachala XX veka), in: Archive of Architecture (Arkhiv arkhitektury), vol. 2, Moscow, 1992, p. 39 [in Russian].

[8] S.A. Shcherbatov, The Artist in Russia Past (Khudozhnik v ushedshei Rossii), Soglasie Publ., Moscow, 2000, p. 232 [in Russian].

[9] A.N. Benois, Diary, 1916-1918 (Dnevnik. 1916-1918), Zakharov Publ., Moscow, 2016, p. 128 [in Russian].

[10] I. Pechenkin, Y. Starostenko, A. Vyazemtseva, The Architect and the Revolution: Architectural Life in Russia in Times of Change (Zodchii i revoliutsiia: arkhitekturnaia zhizn' Rossii v epokhu peremen), Quaestio Rossica 8 (2) (Jun. 2020) 473-487.

DOI: https://doi.org/10.15826/qr.2020.2.475 [in Russian]. 
[11] Berthold Lubetkin. Unpublished notes for 'Samizdat by Anarchitect'. The UK. London. RIBA Archive. LuB/25/4

[12] Berthold Lubetkin. Unpublished notes for 'Samizdat by Anarchitect'. The UK. London. RIBA Archive. LuB/25/4. P. 6

[13] Berthold Lubetkin. Unpublished notes for 'Samizdat by Anarchitect'. The UK. London. RIBA Archive. LuB/25/4. P. 36

[14] The UK. London. RIBA Archive. LuB/11/1/3

[15] The UK. London. RIBA Archive. $\mathrm{LuB} / 13 / 1 \mathrm{~A} / 3$

[16] J. Allan, Berthold Lubetkin. Architecture and the Tradition of Progress, Artifice Books, 2012, p. 22.

[17] Berthold Lubetkin. Unpublished notes for 'Samizdat by Anarchitect'. The UK. London. RIBA Archive. LuB/25/4. P. 37.

[18] K. Malich, I am Amazed by Everything I See" Trips of British Architects to the USSR. On the Question of the perception of Soviet Architecture and the Features of Communication between English and Soviet Architects in 1920-1930s (Ya porazhen vsem uvidennym: poyezdki britanskikh arkhitektorov v SSSR. K voprosu o vospriyatii sovetskoi arkhitektury i ob osobennostyakh kommunikatsii mezhdu angliiskimi i sovetskimi zodchimi v 1920-1930 gody), Vestnik of Saint Petersburg University Arts, 3 (2020) 475-484. DOI: https://doi.org/10.21638/spbu15.2020.306 [in Russian].

[19] F. Patti, Boris Iofan in Rome: Professional Training, Contacts, Design and Realized Buildings: between 1914 and 1924, in: M. Kostyuk, Boris Iofan. Architect behind the Palace of Soviets, Dom publishers, Berlin, 2019.

[20] I. Ejgel, Boris Iofan, Strojizdat, Moscow, 1978, p. 184 [in Russian].

[21] P. Cimbolli Spagnesi, "The Royal Institute of Fine Arts in Rome and the Foundation of the Higher School of Architecture" ("Il Regio Istituto di Belle Arti di Roma e la Fondazione della Scuola Superiore di Architettura"), in: Roccasecca P. (Ed.) "Accademia di Belle Arti di Roma, Centoquaranta anni di istruzione superiore dell'arte in Italia" ("Academy of Fine Arts in Rome, One hundred and forty years of higher art education in Italy", De Luca editore, Rome, 2018, pp. 69-78 [in Italian].

[22] F. Patti, "Boris Iofan (1891-1976), From the Roman years to his professional rise in the Soviet Union" ("Boris Iofan (1891-1976), Dagli anni romani all'ascesa professionale in Unione Sovietica"), Ph. D. Thesis, Politecnico di Torino, Politecnico di Milano, 2009 [in Italian].

[23] Vyacheslav Ivanov Archive, Rome, Personal papers of Andrei Beloborodov, folder 10.

[24] A. Chichkine, Leonid Brailowsky in Rome (new materials) (Leonid Brailovskii v Rime (novye materialy)), in: Paralleli: studi di letteratura e cultura russ, Per Antonella d'Amelia, Salerno, 2014, pp. 437-453 [in Russian].

[25] P. Nardecchia, "The fishermen's village in Ostia: the coast, the canal and the pine forest of Castel Fusano" ("Il Borgo dei pescatori a Ostia: il litorale, il canale e la pineta di Castel Fusano"), Nuova prhomos, Rome, 2013, p. 93 [in Italian].

[26] Historic archive of the "Ordine degli architetti PPC di Roma e Provincia", Membership card n. 135, issued on August, 2, 1929.

[27] M. Talalay, Russian Ortodox Church in Rome (Russkaia Pravoslavnaia Tserkov' v Rime), Rome, 1994 [in Russian].

[28] E. von Neipperq, S. Texier, "André Beloborodoff: Architect, painter, scenographer" (André Beloborodoff: Architecte, peintre, scénographe), Edition Norma, Paris, 2018 [in French].

[29] Vyacheslav Ivanov Archive, Rome, Personal papers of Andrei Beloborodov, folder $11 \mathrm{~b}$. "Villa Giacomaniello".

[30] I. Kazus', Soviet Architecture of the 1920s: Organization of Design (Sovetskaia arkhitektura 1920-kh godov: organizatsiia proektirovaniia), Progress-traditsia, Moscow, 2009, p. 345 [in Russian].

[31] K. Afanasiev, From the History of Soviet Architecture. Documents and Materials (Iz istorii sovetskoi arkhitektury. Dokumenty i 
materialy), Academy of Science of USSR, Moscow, 1963, p. 214 [in Russian].

[32] S. Khan-Magomedov, Konstantin Melnikov, Strojizdat, Moscow, 1993, p. 52 [in Russian]

[33] Yu. Bocharov, S, Tkachenko, Formation of the Capital Functions of Moscow in the City Planning Structure from 1918 to 2018 (Formirovanie stolichnykh funktsii Moskvy v planirovochnoi strukture goroda s 1918 po 2018 god), Academia. Architecture and construction (Academiia. Arkhitektura i stroitel'stvo) 3 (2019) 58-69. DOI: 10.22337/2077-9038-2019-3-58-69 [in Russian].

[34] Kinotvorchestvo Teatr 18-19 (1926) [in Russian].

[35] F. Albera, "Russian Albatross in Paris (19191929)" ("Albatros des russes à Paris (19191929)"), in: Cinémathèque française, Edizioni Gabriele Mazzotta, Paris/Milan, 1995, pp. 9394 [in French].

[36] R. Dornès, "A building in Paris, Fidler architect" ("Un immeuble à Paris, Fidler architecte"), in: Art et Décoration, 1 (1937), pp. 97-102 [in French]. 